\title{
Influence of Discrimination in the Field of TESOL: Perspectives of Mexican EFL Teachers ${ }^{1}$
}

Influencia de la Discriminación en el Campo de la Enseñanza del Inglés: Perspectivas de Maestros de Inglés en México

\section{Edgar Emmanuell Garcia Ponce ${ }^{2 *}$}

Universidad de Guanajuato, Mexico

1 Received: March 1st 2020/ Accepted: September 30th 2020

2 ee.garcia@ugto.mx 


\section{Abstract}

In the last few decades, several studies have documented the discrimination that teachers face in the field of Teaching English for Speakers of Other Languages (TESOL). To date, these studies have shown that discrimination tends to be motivated by issues concerning the native- versus non-native language status of these professionals. Moreover, recent studies have suggested that discrimination in TESOL is intricate involving factors which are associated with the language status of teachers, their pronunciation, gender, race, sexual preference, age, among others. However, despite the fact that there is research discourse which has revealed the struggles of these professionals, no research discourse, to my knowledge, has documented the extent to which this phenomenon impacts on the professionals' feelings, perceptions of the profession, and decision making. In response to this, the present study was conducted to understand the influence of discrimination in the field of TESOL in Mexico from perspectives of 78 Mexican English as a foreign language (EFL) teachers. Through an online questionnaire, the teachers were asked to describe the instances in which they felt discriminated, and how these influenced their feelings, perceptions concerning their profession and decision making. The results show that the discrimination practices impact in complex ways, showing a negative influence on the professionals' feelings, perceptions of the profession, and decisions regarding their current profession. The findings of this study call for more effective strategies in order to stop the discriminatory acts that English language teachers commonly face.

Keywords: discrimination; Mexican TESOL; EFL teachers; Effects of Discrimination; Perceptions

\section{Resumen}

En recientes décadas, varios estudios han documentado la discriminación que profesores han experimentado en el área de la enseñanza del inglés. Hasta la fecha, se ha mostrado que la discriminación en esta área es mayormente motivada por cuestiones de estatus de lengua de los profesores y la distinción entre el ser nativo y no-nativo. Recientemente, se ha sugerido que la discriminación en TESOL puede ser iniciada por un amplio número de factores que son complejos por naturaleza. A pesar de que se han mostrado las dificultades que estos profesionistas experimentan comúnmente en este campo, no se ha mostrado hasta el momento la forma en que este fenómeno impacta en sus emociones, percepciones de la profesión y toma de decisiones. En respuesta a esto, el presente estudio se realizó para entender la influencia de la discriminación en el campo del TESOL a través de las voces de 78 maestros de inglés como lengua extranjera en México. Con la ayuda de un cuestionario en línea, se le preguntó a los maestros describieran las veces en las que se han sentido discriminados, y cómo esto ha tenido un impacto en sus emociones, percepciones de la profesión y toma de decisiones. Los resultados muestran que la discriminación percibida por estos maestros tiene un impacto de manera compleja y afecta significativamente sus emociones, percepciones de la profesión y sus decisiones como profesionistas. Esto hace un llamado a formular estrategias efectivas para erradicar este problema el cual continúa afectando a maestros de inglés. 
Palabras clave: Discriminación; TESOL; maestros de inglés; enseñanza del inglés; efectos; percepciones

\section{Resumo}

Em recentes décadas, vários estudos documentaram a discriminação que professores experimentaram na área do ensino do inglês. Até a data, mostrou-se que a discriminação nesta área é principalmente motivada por questões de status de língua dos professores e a distinção entre o ser nativo e não-nativo. Recentemente, tem-se sugerido que a discriminação em TESOL pode ser iniciada por um amplo número de fatores que são complexos por natureza. Apesar de que se têm mostrado as dificuldades que estes profissionais experimentam com frequência nesta área, não se tem mostrado até o momento a forma em que este fenômeno impacta nas suas emoções, percepções da profissão e tomada de decisões. Em resposta a isto, o presente estudo foi realizado para entender a influência da discriminação na área do TESOL através das vozes de 78 professores de inglês como língua estrangeira no México. Com a ajuda de um questionário em linha, perguntou-se aos professores que descreveram o número de vezes nas que se sentiram discriminados, e como isto tem tido um impacto nas suas emoções, percepções da profissão e tomada de decisões. Os resultados mostram que a discriminação percebida por estes professores tem um impacto de forma complexa e afeta significativamente as suas emoções, percepções da profissão e as suas decisões como profissionais. Isto faz uma chamada a formular estratégias efetivas para erradicar este problema, o qual continua afetando a professores de inglês.

Palavras chave: Discriminação; TESOL; professores de inglês; ensino do inglês; efeitos; percepções 


\section{Introduction}

or decades, research has shown the prevalence of discriminatory practices in the field of TESOL in different parts of the world (Figueiredo, 2011; Louber, 2017; Mahboob \& Golden, 2013; Ruecker \& Ives, 2014; Selvi, 2014). Much of this research has suggested that these discriminatory practices tend to be motivated by the distinction between the native and non-native status of English teachers (see Braine, 2010; Holliday, 2005; Kamhi-Stein, 2004; Kubota, 2004; Kubota \& Lin, 2009; Llurda, 2005; Moussu \& Llurda, 2008). Recently, it has been suggested that the discrimination in TESOL is far more complex than we thought; there is an array of factors which can motivate discrimination against English as a foreign language (EFL) teachers. These factors are associated with the language status of teachers, their pronunciation, gender, race, sexual preference, age, among others. Evidence of this comes from The Author (2017) which showed that a high number of Mexican EFL teachers have faced a wide range of discriminatory practices which are professionrelated, physical, and linguistic in nature.

In the research literature, the primary aim of investigating the discriminatory practices in TESOL worldwide has been to eradicate this phenomenon. However, it seems that the main obstacle is that stakeholders in TESOL, i.e., administrators, teachers, students and parents, do not often know about this phenomenon and how it affects EFL teachers (Lengeling, Crawford, Mora Pablo \& Blomquist, 2016). Thus, it is highly important that we direct our efforts towards raising awareness of this problem. To do this, there is a need to understand both the nature of discrimination in TESOL and the influence it has on English teachers' feelings, perceptions of the profession, and decision making. To contribute to this, the purpose of this study is to explore how discrimination in TESOL influences the feelings, perceptions of the profession, and decisions of 78 Mexican EFL teachers. The study is guided by the following research question: What is the perceived influence that discriminatory acts have on the Mexican EFL teachers' feelings, perceptions of the TESOL profession, and decision making?

As suggested in this research question, the importance of this study is that it provides an examination of the extent to which discrimination in the field of TESOL have an impact on the realities of these professionals who dedicate their time to teach the English as a foreign language (EFL). Therefore, the insights gained from this study will contribute to existing knowledge of the nature of discrimination in the TESOL profession in Mexico. 


\section{Background}

In the research literature, several definitions of 'discrimination' have been suggested. This is because the concept of discrimination is complex in nature (The Author, 2017), that is, it is often motivated by several factors whose essence is also intricate. For the purpose of the present study, the study adapts The Author's (2017) definition of discrimination in TESOL as prejudiced actions which are motivated by gender, ethnicity, physical appearance, temporal or permanent physical or cognitive impediment, and linguistic competence (involving pronunciation, accent or any linguistic aspect related to the language) which initiate inequalities for obtaining resources or opportunities in the profession of foreign language teaching. This definition and others have been a timely attempt to define the complex construct of discrimination in the TESOL profession. However, this article will show that discrimination in the Mexican TESOL not only initiate inequalities for obtaining resources or opportunities in the profession, but also have important effects on the Mexican EFL teachers' feelings, perceptions concerning the profession, and their decision making concerning their professional lives.

In general, discrimination has been observed in different contexts and through different lenses. In the case of education, discrimination has been seen to be motivated by "actions of institutions or individual state actors, their attitudes and ideologies, or processes that systematically treat students from different racial/ethnic groups disparately or inequitably" (Mickelson, 2003, p.1052). As previously mentioned, this is a problem that still exists in the TESOL profession in Mexico and worldwide, despite the presence of position statements against it, for example:

TESOL is opposed to discrimination that affects the employment and professional lives of the TESOL members on the grounds of race, ethnicity, nationality, language background, disability, health/medical condition, including HIV/AIDS, age, religion, gender, gender identity, and sexual orientation. (TESOL, 2016)

According to The Author (2017), the prevalence of discrimination in TESOL is due in large part to the ignorance of students, teachers and administrators. Drawing upon my experience as an EFL teacher, I have perceived that discrimination is often motivated by factors which are associated with teachers' gender, ethnicity, temporal or permanent physical impediment, and linguistic competence. My own perception, fed by comments from other colleagues working in the same field, suggest the possibility that discriminatory practices in the Mexican TESOL still exist and in different forms, and might continue to affect thousands of professionals who teach the language in 
Mexico and other EFL contexts. The idea that discrimination is still alive in the Mexican context is supported by recent research evidence (see The Author, 2017; Lengeling et al., 2016). For example, The Author (2017), in a small-scale study conducted at a state university in Mexico, found that a high number of EFL teachers have experienced some kind of discrimination while looking for jobs or working in the Mexican TESOL. Based upon their evidence, they call for contextually sensitive research because they maintain that the nature of discrimination in TESOL is context dependent, and this nature changes from one context to another one. These investigations would contribute to bringing this evidence to light, formulating strategies to prevent discrimination in this field, and continue raising awareness among stakeholders of discriminatory behaviours in the profession. In general, they maintain that all efforts need to be directed towards evidencing and eradicating the discriminatory practices.

However, in Mexico, little is known about this social phenomenon within the TESOL field. Only a limited number of studies have been carried out to explore the non-native speaking teachers (see The Author, 2017; Lengeling et al., 2016). Therefore, much needs to be done to look at cases where participants describe the discriminatory acts that they have faced in the Mexican TESOL profession and the likely influence of these acts. Taking up this call for such investigations, the present study set out to explore how discrimination in the Mexican TESOL influences 78 EFL teachers' feelings, perceptions of the TESOL profession, and decision making. By doing so, the study makes several contributions to the current research literature. Firstly, this research provides additional evidence with respect to discrimination in TESOL. Secondly, its results add to a growing body of literature on the influence of discrimination in TESOL.

\section{Methodology}

Whilst several studies have shown that discrimination is still alive in the TESOL field (Figueiredo, 2011; Louber, 2017; Mahboob \& Golden, 2013; Ruecker \& Ives, 2014; Selvi, 2014), no studies have been found which document the influence of discrimination on EFL teachers' cognitions (feelings, perceptions, beliefs) and profession-related decisions. Much less is known about the nature of this influence and the role it plays in their professional lives.

In response to the above, the present study explores the influence of discrimination in TESOL on the feelings, perceptions of the TESOL profession, and decision making of a group of EFL Teachers in Mexico. To do this, the study adopted a qualitative approach because this approach is believed to offer an effective way of describing "social phenomena as they occur naturally" (Dörnyei, 2007, p. 38). This was particularly relevant for the purpose of the study as it attempts to develop an understanding of 
the potential influence of the discrimination that EFL teachers face EFL teaching and learning contexts. Moreover, because the focus of the study is individuals' subjective opinions, experiences and feelings, a qualitative approach was appropriate for understanding "the participants' views of the situation being studied" (Dörnyei, 2007, p. 38), that is, the kind of discrimination that they have experienced in the Mexican TESOL profession.

\section{Data Collection Procedures}

In order to collect the data, a web-based questionnaire was administered on SurveyMonkey. According to Wright (2005), online questionnaires are useful because they allow researchers to gain access to individuals and groups who would be difficult reach through other means and channels. The link to the questionnaire was sent out to EFL teachers in Mexico through open calls posted on social media, or directly sent to schools and contacts. The link was active for approximately four months. In order to participate in the study, the individuals had to meet two self-reported criteria: 1) they had to be non-native speakers and 2) EFL teachers in Mexico.

In total, 78 EFL teachers responded the online questionnaire: 52 females and 26 males. As stated by the participants, they had a wide range of teaching experience, from different Mexican states, working in public and private sectors, and teaching in preschool, primary, secondary, high school and university. The questionnaire consisted of ten close-ended and open-ended questions (see Appendix I). All the questions asked for information regarding any discrimination practices that the EFL teachers have felt in the profession. In order to understand the influence of discrimination in the Mexican TESOL profession, some question items asked the participants to describe the discriminatory acts that have been initiated against them, and how they felt that these acts have influenced their perceptions concerning their teaching practices, feelings, and the TESOL profession in general (please see items 6-10 in Appendix I).

At the end of the online questionnaire, the participants were informed of their right to withdraw from the study, and provided consent. Complying with their right to be protected from identification, the participants' names and identities were carefully anonymised in the data. Instead, the word 'Participant' and an identification number are used to refer to them in the extracts, analysis and discussions.

\section{Data Analysis}

Once the data were gathered in the online questionnaire, there were transferred to a Word document for processing. The analysis of the elicited data firstly consisted of reading through the participants' responses a number of times to identify emerging 
themes which suggested the influence of discrimination in the Mexican TESOL. The data were then categorised by identifying extracts manually in the Word document, and attributing them to themes which emerged from the data. Finally, the emerging themes were condensed, and the following themes were found:

1. The Negative Influence of Discrimination in TESOL

\subsection{Feelings of Frustration and Disappointment}

1.2. Negative Perceptions of the TESOL Profession

\subsection{Negative Perceptions of Teachers' Non-Native Status}

\subsection{Negative Self-Concepts}

\subsection{Low Salaries, Social Welfare and Funding for Research}

\subsection{Job Abandonment}

The analysis of the data suggested one main theme (The Negative Influence of Discrimination in TESOL). Within this theme, sub-themes were found which provide support to my argument that discrimination in the TESOL profession impacts in negative ways.

\section{Data Analysis And Discussion}

In this section, the results of the present study are outlined and discussed in order to answer the research question (i.e., What is the perceived influence that discriminatory acts have on 78 Mexican EFL teachers' feelings, perceptions of the TESOL profession, and decision making?). In general, the results suggest that the discriminatory practices initiated against the participants have exerted influence which can be categorised as negative. Specifically, these practices seem to have had an impact on the Mexican EFL teachers' feelings, perceptions regarding the profession, and decision making. Moreover, the evidence suggests that the discrimination practices has sometimes resulted in inequalities concerning job conditions for them or the abandonment of their jobs or profession permanently. In the following sections, I discuss these results in greater detail.

\section{Discrimination in TESOL: Negative Influence}

In the web-based questionnaire, all the participants claimed to have experienced discriminatory practices in the Mexican TESOL. When asked them to describe the 
way these practices influence, the majority of the participants' responses suggested that the discrimination in the Mexican TESOL has had a negative influence. Table 1 summarises their perceived influence.

Table 1. The Influence of discrimination in Mexical TESOL

\begin{tabular}{|c|c|}
\hline Negative Influence & $87.1 \%$ (68 participants $)$ \\
\hline No Influence & $12.8 \%$ (10 participants $)$ \\
\hline
\end{tabular}

As can be seen in Table 1, 87.1\% of the participants described discrimination practices which were categorised as having a negative influence. $12.8 \%$ of the participants' responses suggested that the discrimination that they have experienced has not had any impact; these practices were categorised as having no influence. The data in Table 1 then means that from the $100 \%$ of these teachers who claimed that they have experienced some kind of discrimination, $87.1 \%$ of these teachers have faced discrimination which has influenced in some negative way. In the following sections, I provide qualitative data which support my argument that the discrimination practices not only influence the teachers' perceptions of the profession and their self-concepts, but also initiate an array of inequalities which may motivate teachers to obtain more training or quit jobs.

\section{Feelings of Frustration and Disappointment.}

When asked to describe the influence of the discrimination practices that they have experienced, 31 participants claimed that they have felt negative feelings, for example:

- $\quad$ Vulnerable and mad (Participant 3)

- $\quad$ Unimportant (Participants 72, 40 and 69)

- $\quad$ Underestimated (Participant 29)

- $\quad$ Marginalized (Participant 25)

Exploring the dataset, it was evident that discrimination practices in TESOL tend to influence EFL teachers' feelings in a negative way. As suggested in the remainder of this paper, discrimination practices in influencing their feelings compel teachers to make decisions, sometimes seeking for more teacher preparation but in some occasions abandoning the TESOL field.

The most recurrent negative feeling that 21 participants alleged that they have had when facing discrimination in TESOL was 'frustration', as shown below. 
It is frustrating to deal with the general perception that an English teacher is less qualified, less knowledgeable about teaching.

Extract 1. Participant 38

Frustration that I can anticipate not being treated fairly and being passed over for salary and opportunities for promotion; perceiving white foreigners being better paid and getting promotions despite having lesser qualifications or experience.

Extract 2. Participant 34

They affect me because I consider I have made a great effort to speak and learn English and employers just prefer native speakers. Some of them don't have any qualifications to teach, though.

Extract 3. Participant 17

As can be seen in these three extracts, Participants 38, 34 and 17 have felt different discrimination practices which have initiated feelings of frustration. In Extract 1, Participant 38's feeling of frustration was motivated by misperceptions of other colleagues concerning English teaching. Extracts 2 and 3 show that the feelings of frustration have been motivated by perceived inequalities concerning low salary, race and nativeness. Another feeling which was recurrent in the data was 'disappointment' as follows.

Discrimination make me feel disappointed. 1. Mentioning that women tend to be more committed than men is [sic] only an opinion. People should not base their decisions on opinions. 2. When in institutions prefer a language certificate over a TESOL degree [...] I've seen people with a BA in Tourism getting an English teaching job because their TOEFL score was slightly higher than people with a BA in TESOL.

Extract 4. Participant 43

In Extract 4, Participant 43 suggests that feelings of disappointment have been initiated by opinions and institutional requirements. In 'Mentioning that women tend to be more committed than men is [sic] only an opinion', we can see how he has felt discrimination against this male participant because of his gender and thus feelings of disappointment. In 'institutions prefer a language certificate over a TESOL degree', he has also felt discrimination which again has triggered feelings of disappointment. As evidenced elsewhere (see The Author, 2017), it can be seen that discrimination 
practices can be motivated by an array of practices. As shown in Extracts 1-4, these practices influence the participants' feelings which motivate them to see the TESOL field and themselves differently, and sometimes at a disadvantage compared to other colleagues. This argument is reinforced by other data which show other feelings of disappointment motivated by perceived inequalities compared to English native speakers.

I was disappointed that 9 years of teaching experience were not enough because I was not native speaker, and my accent was not perfect.

Extract 5. Participant 68

It sometimes discourages me to see that the TESOL profession in Mexico is mostly in the hands of a few, most of them native speakers. However, I also believe that we non-native speakers need to earn our position in a world, which clearly give an unfair advantage to native speakers, by working twice as hard. We need to overcome the stereotypes as well as to fight the oppression of some native speakers which refuse to let the control of TESOL.

Extract 6. Participant 34

Again, feelings of disappointment can be seen in Extracts 5 and 6. In 'I was not native speaker and my accent was not perfect' and 'the TESOL profession in Mexico is mostly in the hands of a few, most of them native speakers', Participants 68 and 34 , respectively, have perceived themselves to be at a disadvantage because of their non-native language status. What these two extracts suggest is that the preference for native speakers still prevails in the TESOL field, and this can motivate disappointment in non-native English teachers when compared to native speakers. It is interesting to see in 'We need to overcome the stereotypes as well as to fight the oppression of some native speakers' that discrimination, alongside feelings of disappointment, can encourage teachers to perceive the TESOL profession differently. The following section shows how the discriminatory acts encourage teachers to have a negative perspective of the TESOL profession.

\section{Negative Perspectives on the TESOL Profession.}

The data also suggested the participants' negative perspectives of the TESOL profession because of discriminatory practices initiated against them. Because of perceived inequalities in the TESOL profession, six participants considered the field as "racist". Several reasons were provided by the participants, but these tended to be related to nativeness and race, as follows. 
TESOL is a very racist profession, especially at upper institutions.

Extract 7. Participant 34

In Mexico, there is no equality for everybody.

Extract 8. Participant 64

Because of these perspectives on TESOL as a racist field, this appears to have triggered other negative perspectives on the TESOL field, as suggested in the extracts below.

In Mexico we are far from having a real and professional TESOL environment.

Extract 9. Participant 36

It makes you think that English teaching in Mexico it's a joke! Nobody gets serious about it [the profession].

Extract 10. Participant 72

As can be seen in these extracts, Participants 36 and 72 suggest negative perspectives concerning the field. Specifically, in 'Nobody gets serious about it [the profession]', Participant 72 implies a feeling of hopelessness concerning the discrimination he has felt in the field. What is alarming is the possibility that negative perspectives like these may in turn lead EFL teachers to question their teaching abilities, practices and choice of profession. This suggestion is supported by the following extracts.

It makes me feel my job is worthless or cheap.

Extract 11. Participant 63

It has made me question my choice of career. Sometimes I regret being in the TESOL field, but it's too late to change now.

Extract 12. Participant 8

It caused me to question my dedication to teaching.

Extract 13. Participant 25

Because of the discrimination that the participants have felt in the Mexican TESOL profession, this appears to motivate them not only to have negative perspectives concerning the field, but also to question their teaching practices and abilities. In the 
following sections, I provide more evidence which suggest that discrimination in the Mexican TESOL field has an impact not only on the way EFL teachers perceive the field, but also on their perceptions of their self-efficacy as teachers.

\section{Negative Perspectives on Teachers' Non-Native Status}

As reported in previous studies (Llurda, 2005; Mora Pablo, 2011; Moussu \& Llurda, 2008), discrimination in TESOL tends to be initiated by inequalities concerning the language status of teachers, native vs. non-native. It is surprising, yet alarming, that in this study, there was an important number of participants (18) claiming that they have felt some kind of discrimination due to their non-native status, as shown below.

I went to a language school looking for a job and they told me that they only hired British native speakers, it did not matter if they were language teachers or not. For them, it was important to be British because it was better for the students' learning process.

Extract 14. Participant 46

Teachers who were native speakers or had completed high school in the US were promoted after a couple of months; the others had to wait to get trained ever for a year. Native speakers with little or no experience in TESOL are preferred as ideal candidates for a teaching job.

Extract 15. Participant 36

I feel that some Mexican learners believe that native speakers of English are better teachers when compared to their Mexican counterparts

Extract 16. Participant 76

As shown in Extracts 14-16, the participants have felt discrimination against because they have perceived a preference for English native speaking teachers in the labor market. Moreover, these extracts suggest that this kind of discrimination can be initiated because of the language (native/non-native) status of teachers, but also their race, implying a disadvantage for those who are not white. In line with this evidence, Authors, such as Amin (2001) and Tang (1997), have argued that teachers who are not white Anglo-Saxon and do not look like native speakers of English can be subject to racial discrimination when teaching, mainly in English speaking countries. What is surprising is the evidence that this kind of discrimination can be motivated by both administrators or employers (see Extracts 14 and 15) and students (Extract 16), and the fact that these practices have been documented in other studies which were conducted 
in non-native English speaking countries like Mexico (see, for example, The Author, 2017; Lengeling et al., 2016). As also reported in the studies previously mentioned, the participants suggested that the preference for native speaking teachers resulted in inequalities for obtaining resources or opportunities in the TESOL profession. This study was not the exception; five participants stated that the preference for native teachers in their teaching contexts has resulted in limited work-related opportunities, as suggested in Extract 17.

Usually native speakers get promotions, the chance to do more challenging projects or simply they get more holidays (with the excuse of having to travel to other country).

Extract 17. Participant 40

This extract suggests the idea that native English speakers have better teaching opportunities in the TESOL field. This study is unable to corroborate if these acts actually happened; however, the recurrent evidence in this study and others suggest that there might be inequalities concerning teaching opportunities for native and non-native teachers. Again, these practices seem to have had an impact on the way the teachers perceive the profession and themselves as teachers, as suggested in the following extract.

They make you think that they career you are studying has no point because, at the end, they would prefer a native speaker with no BA studies. :( My teaching practice is not affected, but yes, sometimes I doubt of how good is studying a BA if at the end is better just to speak English better than others.

Extract 18. Participant 28

In general, this evidence suggests that administrators and students may prefer native (or) white teachers. The problem is that despite the fact that there is evidence that this preference is perceived as discrimination and position statement against these inequalities, there is growing evidence which suggests that non-native teachers may be perceived by administrators or students as not having the language abilities to teach English compared to native speaking teachers. Of course, more needs to be done regarding how non-native teachers are perceived. One possibility would be to raise awareness of this problem which thousands of non-native teachers may be experiencing in language educational contexts. 


\section{Negative Self-Concepts.}

11 participants suggested responses which show that discrimination in TESOL may have a negative influence on the way they perceive themselves as English teachers and their abilities to teach. This, for example, can be seen in the following extracts:

At that time, it made me feel insecure, it really hurts when people don't believe in you. It made me feel bad, even I doubted about my skills as a teacher.

Extract 19. Participant 46

At the beginning I felt insecure of myself as a teacher, I thought native teachers were better

Extract 20. Participant 77

It makes me feel insecure as a professional and person.

Extract 21. Participant 62

As previously discussed, discriminatory acts in the TESOL profession can be influential on teachers' feelings. These extracts again show that Participants 46, 77 and 62 have felt insecure after facing some kind of discrimination in the field. This in turn suggests that discrimination practices may motivate EFL teachers to question their teaching abilities, as in 'even I doubted about my skills as a teacher' (Participant 46), and their self-efficacy in general, as in 'insecure as a professional and person' (Participant 62). The evidence shown below adds weight to my argument that facing discrimination in the profession may lead teachers to feel 'teaching insecurity', a feeling of being at disadvantage and thus perceptions of not being able to teach as expected.

Sometimes I think I am not really good or enough prepared to teach English, even when I have my certifications, a Master's degree that I studied with a CONACYT scholarship.

Extract 22. Participant 9

I realized that in those institutions it was more important to be interesting than to be a good teacher. This made me feel helpless and defeated, since I was not able to compete with younger, single co-workers who would get all the opportunities.

Extract 23. Participant 11 
So far, we have seen that discrimination in the TESOL field can motivate negative feelings and perceptions concerning the TESOL profession and their teaching and language abilities. This should not be happening in this era when there is a high demand for English teachers in Mexico, and the fact that the number of non-native teachers is increasingly growing worldwide. As we will see in the remainder of this paper, discrimination can also result in work-related inequalities, job abandonment and teachers seeking more teacher training.

\section{Low Salaries, Social Welfare and Funding for Research.}

As a result of the discrimination that the participants have experienced in the Mexican TESOL field, their responses indicated a range of inequalities regarding access to social welfare, research funding and stricter job requirements. As suggested below, seven participants claimed that as a result of the discrimination against them in the profession, they often obtain low salaries and do not have access to social welfare programmes in Mexico.

Unequal salaries, harder to get a job, increase in favoritism to get promotion. The public sees it as low rated professionals and schools often use payments to hinder teachers forcing them to quit.

Extract 24. Participant 57

Well, I have an illness and, although it's not an impediment to work, I cannot tell the true about it in the school because they won't give me courses to impart. Unfortunately, we are temporary employees, and we don't count with medical services, we have no rights as workers. Our salary is much less than half the base salary, but the obligations are the same, and many times higher.

Extract 25. Participant 69

In Extracts 24 and 25, the participants claimed that they often receive lower salaries than other colleagues, as in 'Unequal salaries' and 'Our salary is much less than half the base salary', respectively. As previously stated, the study is unable to corroborate if these practices actually happened. However, in general, we can see that the participants' responses suggest negative perceptions of the profession ('schools often use payments to hinder teachers forcing them to quit') and themselves as teachers ('The public sees it as low rated professionals'). As indicated in Extract 25, the participant alleges that in her workplace teachers do not have access to social welfare ('we are temporary employees, and we don't count with medical services, we have no rights as workers'). In fact, when teachers are hired to teach per hour (usually short contracts) in Mexico, they do not 
often have access to social welfare which is provided by the Mexican government. Moreover, their responses suggested restrictions not only to better salaries and social welfare, but also to opportunities for research funding, as suggested below.

It made me realize that in Mexico there is so much support for the scientific areas of study whereas there is so little for the humanities. I see it as a challenge for my teaching practice.

Extract 26. Participant 4

In general, the problem of these practices is that more and more English teachers continue to claim that they have experienced some kind of discrimination, and that this results in fewer opportunities for better teaching conditions and opportunities to grow as teachers and/or researchers. As previously discussed, discrimination in the TESOL field can be initiated by students, teacher colleagues and administrators. In the case of administrators, the evidence of this study suggests that sometimes administrators or employers may be aware of motivating discrimination against teachers. This is suggested in the Extract 27.

Now, as a language coordinator, I think I have also practiced discrimination against those colleagues who were looking for an opportunity with the same sentences: Do you have any language certification? What level? Are [you] an undergraduate or graduate student? In my experience, I had to follow the recommendations given by Place 1 in my university, in order to enrol English teachers.

Extract 27. Participant 21

As suggested in Extract 27, Participant 21 states that he has to "follow the recommendations given by Place 1 in my university, in order to enrol English teachers". Based upon this, it is thus possible that discrimination in the TESOL profession is also motivated by institutional requirements and philosophies which may compel employers to initiate discriminatory practices, even if they are aware of them. As suggested below, the results of discrimination or the discriminatory acts themselves may have an impact on teachers abandoning their jobs or seeking for further English teacher training as a way to avoid discrimination in the Mexican TESOL profession. 


\section{Job Abandonment}

Because of the influence of discrimination in the Mexican TESOL, some participants (23) mentioned that they have decided to leave their jobs or the profession permanently, as follows.

At the beginning, it was hard to accept that [the discriminatory act]. That pushed me to quit that job to find a better place for professional development.

Extract 28. Participant 35

It [discrimination] means you have to keep looking for the right place to work.

Extract 29. Participant 70

As can be seen in these two extracts, because of the influence of the discrimination that they have felt, the two participants state that they decided to quit their former jobs. As suggested in the extracts below, it seems that the influence that discrimination in the profession exerted on the teachers compelled them to abandon the profession. This can be seen in the following extracts.

I decided to get a BA on something that might eventually lead me to something completely different than teaching

Extract 30. Participant 49

I have recently been thinking of quitting teaching. If I could earn as well as native speakers do, I wouldn't think of quitting.

Extract 31. Participant 61

These extracts thus suggest that the discriminatory practices that the participants have experienced in the TESOL profession not only had an impact on their feelings and perceptions of the profession, but also compel them to make profession-related decisions, that is, decisions to quit their jobs or abandon the profession permanently. In summary, the evidence presented in this study suggests that the discrimination that the teachers have faced in the Mexican TESOL field influenced their professional lives in complex ways. This can be from negative feelings; negative perceptions of the field; limited teaching, medical and research opportunities; and abandonment of their language teaching jobs or profession. All in all, this evidence has provided new insights into the influence of discrimination of TESOL on the teachers' professional lives. 


\section{Conclusions}

The present study explored how discrimination in TESOL impacts on EFL teachers' feelings, perceptions regarding the TESOL profession. The present study was conducted with the intention of 1) documenting these practices and how they negatively influence the teachers' perceptions and decisions, and 2) reaching more and more people to take a more agentive role against discrimination practices in the field of TESOL in Mexico.

As evident in the perceptual data, 78 Mexican professionals have experienced some kind of discrimination in the TESOL profession. As suggested in their responses in the web-based questionnaire, the discrimination that they have experienced has significantly influenced their feelings, perceptions of the profession, and their decision making concerning their professions. Some inequalities were also mentioned by the participants as a result of the discrimination that they claimed to have experienced. These were related to salaries, medical care and research opportunities. As a result of the influence of the discriminatory practices, the participants stated that they have decided to abandon their jobs or the teaching profession permanently. Throughout this article, the data were carefully treated because the study was unable to corroborate if these discriminatory practices and inequalities actually happened in practice; however, the growing evidence presented here and in previous studies suggest the possibility that a high number of EFL teachers in our country continue to face inequalities which put them at a disadvantage.

The above evidence calls for effective strategies to eradicate discrimination in our field because, as shown in this paper, a growing number of EFL teachers continue to claim that they have felt some kind of discrimination which has impacted in negative ways. It is thus important to continue raising awareness among the TESOL community which involves students, teachers, administrators and employers. One possibility would be to inform the education community of these practices, or invite them to participate in workshops whose objectives are to eradicate discrimination practices in TESOL.

Of course, more needs to be done to reach those people who intentionally or unintentionally initiate discrimination against English teachers. There is also a need to conduct further research. It would be helpful to carry out research projects which seek to understand discriminatory acts in TESOL and, based on the findings, formulate strategies which are sensitive to teaching and learning contexts. However, the present study has gone some way towards gaining further understanding of the discriminatory acts that professionals experience within TESOL in Mexico. It is hoped that this study raises awareness of the disadvantageous realities of Mexican teachers which may also be similar or different to other contexts in our profession. 


\section{References}

Amin, N. (2001). Nativism, the native speaker construct, and minority immigrant women teachers of English as a second language. The CATESOL Journal, 13(1), 89-107.

Braine, G. (2010). Nonnative speaker English teachers: Research, pedagogy, and professional growth. New York: Routledge.

Dörnyei, Z. (2007). Research methods in applied linguistics. Oxford, UK: Oxford University Press.

Figueiredo, E. H. D. de. (2011). Nonnative English-speaking teachers in the United States: issues of identity. Language and Education, 25(5), 419-432. http://doi.org/1 0.1080/09500782.2011.574702

Holliday, A. (2005). The struggle to teach English as an international language. Oxford: Oxford University Press.

Kamhi-Stein, L. (Ed.) (2004). Learning and teaching from experience: Perspectives on nonnative English-speaking professionals. Ann Arbor: University of Michigan Press.

Kubota, R. (2004). Native speaker: A unitary fantasy of a diverse reality. The Language Teacher, 28(1), 3-10.

Kubota, R. \& Lin, A. (Eds.) (2009). Race, culture, and identities in second language education: Exploring critically engaged practice. New York: Routledge.

Lengeling, M., Crawford, T., Mora Pablo, I., \& Blomquist, N. (2016). Discrimination within the TESOL profession: Perspectives of teachers. Academia Journals, 8(5), 3163-3167.

Llurda, E. (Ed.) (2005). Non-native language teachers. Perceptions, challenges and contributions to profession. New York: Springer.

Louber, I. (2017). Racial Discrimination in TESOL: A Qualitative Study on the Experiences EFL Teachers at a University Preparatory Year Programme in Saudi Arabia. International Journal of Bias, Identity and Diversities in Education, 2(2). https://doi.org/10.4018/IJBIDE.2017070103

Mahboob, A. \& Golden, R. (2013). Looking for native speakers of English: Discrimination in English language teaching job advertisements. Voices in Asia Journal, 1(1), 72-81. http://www.voiceinasiajournal.com/images/pdf/vol1/ File_9_VIAJ_1.1._Mahboob_and_Golden_pp._72-81.pdf

Mickelson, R. A. (2003). When are racial disparities in education the result of racial discrimination? A social science perspective. Teachers College Record, 105(6), 1052-1086. http://dx.doi.org/10.1111/1467-9620.00277 
Mora Pablo, I. (2011). The "native speaker" spin: the construction of the English teacher at a language department of a university in Mexico. Unpublished doctoral thesis of Canterbury Christ Church University.

Moussu, L. \& Llurda, E. (2008). Non-native English-speaking English language teachers: History and research. Language Teaching, 41(3), 315-348.

Ruecker, T., \& Ives, L. (2014). White native English speakers needed: The rhetorical construction of privilege in online teacher recruitment spaces. TESOL Quarterly, 49(4), 733-756. https://doi.org/10.1002/tesq.195

Selvi, A. F. (2014). Myths and misconceptions about nonnative English speakers in the TESOL (NNEST) movement. TESOL Journal, 5, 573-611. DOI: http://dx.doi. org/10.1002/tesj.158

Tang, C. (1997). On the power and status of nonnative ESL teachers. TESOL Quarterly, 31(3), 577-580.

TESOL (2016). Position statement opposing discrimination. Retrieved from: http:// www.tesol.org/docs/default-source/advocacy/tesol-position-statement-opposingdiscrimination.pdf

The Author (2017).

Wright, K.B. (2005). Researching internet-based populations: Advantages and disadvantages of online survey research, online questionnaire authoring software packages, and web survey services. Journal of Computer-Mediated Communication, 10(3). https://doi.org/10.1111/j.1083-6101.2005.tb00259.x

\section{Author}

* Edgar Emmanuell Garcia Ponce PhD in English Language Teaching and Applied Linguistics (University of Birmingham, UK), currently works in the Department of Languages at the University of Guanajuato. His research interests are classroom interactions and teacher cognitions. He has recently worked on projects funded by the British Council. He is a member the Sistema Nacional de Investigadores, and coordinates the BA in ELT at the Universidad de Guanajuato

ORCID: https://orcid.org/0000-0002-5414-3862

How to reference this article: Garcia-Ponce, E. E. (2020). Influence of Discrimination in the Field of TESOL: Perspectives of Mexican EFL Teachers. GIST - Education and Learning Research Journal, 21, 69-89. https://doi.org/10.26817/16925777.837 